To cite: P Andrews 'Editorial: Special focus on "Dignity takings and dignity restorations"' (2018) 18

\title{
Editorial: Special focus on 'Dignity takings and dignity restorations'
}

\author{
Penelope (Penny) Andrews \\ Dean and Professor of Law, University of Cape Town (2016-2018) \\ Sabbatical Scholar, Columbia University School of Law (2018-2019)
}

In her book published in 2014, We want what's ours: Learning from South Africa's land restitution program, Professor Bernadette Atuahene introduced two significant and inter-related concepts, namely, 'dignity takings' and 'dignity restoration'. Atuahene defined 'dignity takings' as the confiscation of property that also involves the dehumanisation of people so dispossessed of their property as well as the deprivation of their dignity.

Atuahene argues that the appropriate remedy for a dignity taking is dignity restoration, a concept based on restorative justice principles. Dignity restoration seeks not merely to compensate for the legal harm, but also to address the dignitas and social harm, thereby restoring to those dispossessed their humanity. The process of dignity restoration, she argued, may also serve to eliminate the vulnerability and recognise and reinforce the agency of those who had been dispossessed.

Professor Atuahene tracks these two concepts by examining the processes of land dispossession and land expropriation in South Africa during colonialism and apartheid and their devastating impact on black individuals and communities (dignity takings). She then explores subsequent steps taken by the post-apartheid democratic government to 'make whole' those who had suffered from the theft of their land, beyond the formal legal process of reparations (dignity restoration).

In this volume of the African Human Rights Law Journal, three contributors examine dignity takings and dignity restoration in three contexts: The first revisits this issue with a focus on the Popela community of Limpopo Province in South Africa whose land was expropriated; the second and third reach geographically beyond South Africa to Kenya and Nigeria, and expand the conceptual moorings of dignity takings and dignity restoration from land and property to the criminalisation of same-sex conduct and the 
deprivation of the property rights of African women under customary law.

In the first article, 'From reparations to dignity restoration: The story of the Popela community', Atuahene and Sibanda explore the plight of the Popela community who were subjected to dignity takings by successive colonial and apartheid regimes. Their struggle was a long and protracted one, but nevertheless offered significant promise. This is because the post-apartheid democratic government publicly committed itself not only to providing reparations to the Popela community and others similarly situated, but also to facilitating the processes of dignity restoration.

Pondering whether the South African government has facilitated or undermined dignity restoration for the Popela community, Atuahene and Sibanda detail a litany of legal and political gains and setbacks in the land restitution process, culminating in a Constitutional Court victory for the Popela community. The judgment signified a comprehensive remedial approach to compensate for the dignity takings of the Popela community and the beginning of the dignity restoration project for them. Despite this legal victory, the South African government failed to follow up on the judgment and provide the relief accorded the community.

Atuahene and Sibanda highlight a lacuna in the effectiveness of socio-economic rights litigation and the ensuing jurisprudence to deliver on the promises of the Constitution to poor and marginalised communities. They point out how court victories that explicitly provide for remedial action to be taken by government are often not followed by executive action in implementing these remedies. As an example, they refer to the significant Constitutional Court decision in Grootboom, ${ }^{1}$ where a combination of indifference and incompetence led to Ms Grootboom dying in her shack several years later, without her and her co-litigants ever receiving the houses that had been to be allocated to them.

Similar indications of official indifference and incompetence are evident in the wake of the Constitutional Court victory for the Popela community, while some in the community also suspect that corruption may be at play in their situation. In a rather dispiriting conclusion, Atuahene and Sibanda show how several years after the court victory, dignity restoration still is not within reach for the Popela community, although the members of the community remain hopeful. The authors warn that the failure to engage in a meaningful process of dignity restoration for the Popela community and others

1 Government of the Republic of South Africa v Grootboom \& Others 2001 (1) SA 26 (CC). 
jeopardises the fledgling constitutional democracy, leading to greater instability that will multiply across South Africa.

In 'From disgust to dignity: Criminalisation of same-sex conduct as a dignity taking and the grassroots battle to achieving dignity restoration', Shaw analyses whether the criminalisation of consensual same-sex conduct in Kenya constitutes a 'dignity taking'. In pursuing his research question, Shaw builds on Atuahene's scholarship on dignity takings, as well as the recent work of legal scholars and social scientists who extend the concept to other spheres of inquiry. These scholars see dignity takings as a useful methodology for understanding the range of dignity-related harms inflicted by the state on individuals and communities.

Although Atuahene and other scholars have cautioned against extending the concept of dignity taking that may dilute its analytic potency, Shaw employs a 'body as property' framework to argue that the criminalisation of same-sex conduct in Kenya constitutes a dignity taking. He sees this framework as an effective way to illustrate that the violation of the bodies of LBGTQ people by the state (through forced medical and other tests), as well as 'othering' LBGTQ people (through stigma) constitute both direct and indirect takings.

As in the property dispossession context, where reparations are not sufficient, so too decriminalising same-sex conduct is insufficient for the purposes of dignity restoration. Shaw points out that decriminalising same-sex conduct is but one step in the process of dignity restoration. What will be required is a range of legal and extralegal steps by the government to combat widespread homophobia that continue to condone violence and discrimination against LBGTQ people.

Shaw questions whether the activism and advocacy by civil society advocates with the specific goal of decriminalising same-sex conduct constitute a form of dignity restoration. He concludes that they probably do not, since same-sex conduct as well as the resultant queer identities remain a crime in Kenya, giving rise to a particularised homophobia ready to be conscripted by opportunistic politicians.

In 'The shadow of legal pluralism in matrimonial property division outside the courts in Southern Nigeria', Diala explores the issue of legal pluralism and specifically the interaction of state and customary law in Southern Nigeria. Building on the work of Atuahene, he argues that the denial of women's rights under customary law to matrimonial property in the case of divorce or death results in dignity takings as such denial ignores the agency of women, especially in the economic realm. Such denial also discounts the capacity of women to make informed decisions regarding their contributions to matrimonial property.

The author notes that dignity takings occur on two fronts. The first is in the private realm, where men rely on customary law to deny women equality in the marriage, in effect treating women as minors, therefore depriving women of their rightful access to matrimonial 
property. The second is a public or state failing, namely, the failure to create the regulatory conditions that might enable women with a rightful claim to marital property, either through constitutional or legislative means.

Diala argues that dignity restoration occurs through the interventions of the state that are mindful of the power inequalities in customary law and therefore act to redress such power imbalance in favour of women. To demonstrate the point, he highlights the active interventions of a government agency, the Social Welfare Department, mandated to protect the rights of women and children. These interventions, according to the author, are 'facilitating a living customary law of matrimonial property', which in no small way contributes to dignity restoration.

The concepts of dignity takings and dignity restoration provide an empathetic and innovative approach to issues of harm and attendant remedies. They centre the experiences of the victims and allow for a fuller recognition of the dimensions and consequences of dispossession, beyond the legal to include the human. Such recognition thereby enables the restoration of dignity and humanity for those previously dispossessed and allows for societal healing, social sustainability and for democracy to flourish.

Professor Atuahene's intellectual contribution to land dispossession through an analysis of dignity takings and dignity restoration has been significant. This special focus furthers the discussion and will hopefully spur scholars and activists to continue to expand our intellectual bandwidth as we continue to address historical harms. 